RESEARCHARTICLE

\title{
Feminism ís African, and other implications of reading Oyèrónké Oyěwùmí as a relational thinker
}

\author{
Azille Coetzee* \\ Department of Philosophy, Stellenbosch University, South Africa
}

\begin{abstract}
In this paper I interpret the work of Nigerian feminist scholar Oyèrónké Oyĕwùmí to be embedded in a relational understanding of the subject that is prevalent in African thought. In other words, when she asserts the "ungenderedness" of the precolonial Yorùbá world, I understand her to base this on an understanding of subjectivity, as developed in African philosophy, that is deeply relational, fluid and non-dichotomous and therefore not reducible to the strict, essentialised, hierarchical and stable gender dyad of the colonial Western gender system. Reading Oyěwùmí's work as sharing certain core metaphysical assumptions with the African philosophers working on relationality, therefore sheds new light on her position. Moreover, read in this way, her work can be argued to, firstly, bridge the disciplinary rift between African thought systems and African feminism, and secondly, to deconstruct the popular notion that feminism is "anti-African". Lastly, I argue that Oyěwùmís work can be used to strengthen and deepen African philosophical theorisations of relational subjectivity, because it highlights, among other things, the way in which certain African cultures and thought systems could be argued to be specifically conducive to progressive forms of gender equivalence. This attests to the unique and important ways in which African feminist voices could contribute to African philosophy.
\end{abstract}

\section{Keywords}

\section{G Open Access}

Citation: Coetzee, A. (2018). Feminism ís African, and other implications of reading Oyèrónké Oyěwùmí as a relational thinker. Gender and Women's Studies, 1(1): 1.

Received: October 20, 2017 Accepted: December 26, 2017 Published: January 10, 2018

Copyright: () 2018 Coetzee, A. This is an open access article distributed under the terms of the Creative Commons Attribution License, which permits unrestricted use, distribution, and reproduction in any medium, provided the original author and source are credited.

\section{Corresponding author:}

Azille Coetzee, Department of Philosophy, Stellenbosch University, South Africa E-mail: azille.coetzee@gmail.com
Oyěwùmí, philosophy, Africa, gender, feminism, relationality

\section{Introduction}

Nigerian feminist scholar Oyèrónké Oyĕwùmí famously argues that gender is a Western cultural construct that did not exist in Yorùbá society prior to British colonial rule in Nigeria. In this article, I situate Oyěwùmí's claims against the backdrop of the substantial body of work in African philosophy analysing and theorising what is argued to be the relational or communalistic notion of the subject prominent in many African cultures and thought systems. I show how Oyěwùmí's claims about the absence of gender in precolonial Yorùbá society can be argued to be rooted in such a fluid and relational understanding of the subject.

I show how, by reading her work in this way, her claims, that are regarded as controversial and have evoked fierce criticism from many, are rendered exceedingly convincing and significant in the context from which she is writing.

In reading Oyĕwùmí's work in dialogue with African philosophy on relationality, I attempt to respond also specifically to two other issues, first, the near absence of feminism and women in African philosophy, and second, the way in which feminism is often framed as a pursuit that is "anti-African" or recolonising.

It is well known that, with a few exceptions, the issue of gender in African societies has not been conceptually addressed by African philosophy (Oyowe \&Yurkivska, 2014, p. 86), even though a lively gender discourse has emerged in other disciplines like African theology, literary studies, anthropology, history and sociology. Oyowe and Yurkivska write in this regard: "(d)espite the perennial problems of gender-related violence, gender discrimination and the 
increasing evidence that African society is in actual fact not gender egalitarian but sexist, African philosophy shows very little concern with gender identity or gender issues" (Oyowe \&Yurkivska,2014, p. 85). Sophie Oluwole, Nigerian philosopher and academic, wrote years back already: "When it comes to philosophy proper, it appears that the main figures in the discipline have almost, in a conspiratorial way, avoided feminist discussion" (Oluwole, 1998. p. 96). Similarly, in 2011, Thaddeus Metz, an American philosopher working in South Africa on African philosophy, writes that "extraordinarily few African women practice professional philosophy, and there is little interest in feminism among the men who principally do" (Metz, 2011, p. 24). Accordingly, not only is there notoriously few African women philosophers, African philosophy is almost completely silent on the issue of feminism."

Closely related to this absence and silence, and possibly a contributing factor, is the issue that woman's emancipation and African liberation (two matters that are equally crucial for African feminist projects), often stand in deep tension with each other, because feminism is in many cases characterised as alien to Africa (Du Toit, 2008, p. 420). Nigerian philosopher and literary scholar Chielozona Eze explains in this regard that "[f]or many Africans, feminism is a curse word" (Eze, 2015, p. 312). Another Nigerian scholar Glo Chukukere goes further and writes that feminism is an outright negation of Africanness (Chukukere, 1998, p.134). iii In African nationalist rhetoric the attempts of feminists to transform gender relations in African societies are often framed as neocolonial and "unAfrican" and therefore pitted against African cultural and traditional identities. In such cases, resisting the transformation of gender relations is therefore regarded to serve the fight against the continued neocolonial imposition of Western values onto African societies and as therefore being part of the preservation of African traditions or cultures. ${ }^{\text {iv }}$ In terms of this view, African feminism's fight for the rights of African women is considered to be a Western or recolonising pursuit and on that basis it is often excluded from African intellectual discourses aimed at producing indigenous knowledges. $^{v}$

By proposing that the work of Oyĕwùmí, as an African feminist scholar, could be argued to share core metaphysical assumptions with a big body of work in the African philosophical tradition, I attempt to traverse these rifts between firstly, African feminism and indigenous African thought, and secondly, African feminist scholarship and African philosophy. By pointing out how the feminist position of Oyěwùmí can be argued to be informed with the relational ontology and metaphysics so prevalent in indigenous African cultures and thought, I show how African feminism can also be a force that sustains and cultivates some of the indigenous conceptual paradigms and worldviews in African thought. The implication is that the struggle for gender equivalence is not necessarily a foreign import in Africa, but can be argued to be fundamentally in line with certain schools of African thought. I also go further to make the point that Oyěwùmís work shows the inherent feminist potential of certain African indigenous understandings of the subject and the world, in other words, that certain schools of indigenous African thought can be interpreted to be specifically conducive to gender equivalence. This opens up new avenues for the development of African relational philosophy. In this way I show the value of the participation of women and the incorporation of feminist thought in the tradition of African philosophy.

In the next section I provide a brief outline of Oyěwùmí's theory of gender in precolonial Yorùbá society. In section three, I relate her arguments to the relational understanding of the subject in African philosophy, after which I outline the implications of such a reading.

\section{Oyěwùmí and the Colonial Invention of Women in Yorùbá Society}

In her book The Invention of Women: Making an African Sense of Western Gender Discourses (1997) Oyĕwùmí famously argues that gender was created in Yorùbá society through the intertwined processes of colonial rule in Nigeria, the translation of Yorùbá into English and the continued dominance of Western knowledge production. Her argument is first and foremost an epistemological one. Oyěwùmí argues that if one succeeds in bracketing Western paradigms, conceptual frameworks and assumptions when researching precolonial Yorùbá society, it becomes clear that this society did not understand and organise the world in terms of gender categories. The gender organisation that one sees among the Yorùbá people today is the result of the imposition of a "gender-saturated colonial epistemology" (Oyěwùmí, 2016, p. 2). Oyĕwùmí shows through a detailed analysis of family organisation, language, divison of labour, religion and oral traditions that, unlike in the West, gender was not originally part of the Yorùbá conceptual framework for making sense of the social world. She argues that 
British colonisation as racial and gendered process was instrumental in the establishment of the existing gender systems among the Yorùbá. Oyěwùmí argues that the continued Western hegemony in knowledge production in terms of which the Western construction of gender is universalised and applied as invisible frame in research on all societies, sustains and reinforces the idea that gender exists as a timeless organising principle in precolonial Yorùbá society.

In pre-colonial Yorùbá society, Oyěwùmí claims, "body type was not the basis of social hierarchy" and biology was not "the foundation for social ranking" (Oyěwùmí, 1997: p. xii). As a result, prior to colonial contact with the West, women in Yorùbá society did not form a preexisting group characterised by shared interests, desires or social position (Oyĕwùmí, 1997, p. ix) because unlike in the West "the body [was] not always enlisted as the basis of social classification" (Oyĕwùmí, 1997, p. 13). In other words, the shared fact of having a female body therefore did not automatically lead to women forming one class and occupying the same positions. Persons were classified into social groups depending on the roles they took up in society and the kind of people they were, and these things were not determined by sexual body type. In this sense, in Yorùbá society you were not primarily a man or a woman, but rather a trader, hunter, cook, farmer or ruler - all these identities being equally accessible to all gendered subjects. Motherhood is the exception here in so far as only women can give birth. Oyěwùmí explains however, that this is only one area of life and although the capacity of women to give birth was taken very seriously and socially celebrated, it did not determine women's position and roles across other spheres of society, such as restricting them to nurturing/domestic roles.

On this basis she writes that the words "woman" and "man" are mistranslations of the Yorùbá obinrin and okùnrin in so far as these words in Yorùbá do not refer to categories that are either binarily opposed or hierarchical (Oyĕwùmí, 1997, p. 32). Unlike the words "(wo)man" and "man" that imply that there is an "original human type against which the other variety has to be measured," "rin" the common suffix of obinrin and okùnrin implies a common humanity inherent to two different kinds of anatomies (Oyĕwùmí, 1997, p. 33). Oyĕwùmí writes:

In the Yorùbá conception, okùnrin is not posited as the norm, the essence of humanity, against which obìnrin is the Other. Nor is okùnrin a category of privilege. Obinrin is not ranked in relation to okùnrin; it does not have negative connotations of subordination and powerlessness, and, above all, it does not in and of itself constitute any social ranking (Oyĕwùmí, 1997, p. 33).

Accordingly, Oyĕwùmí posits a logic in terms of which gender is not understood within, what she argues to be, the Western dichotomy of one/Other in terms of which the masculine is the standard and the feminine is the Other. In her work Oyěwùmí replaces the terms "man" and "woman" with "anamale" and "anafemale" to refer to anatomical males and anatomical females without the hierarchical connotations. When writing about the sexual dynamics in Yorùbá society she thus tries to indicate sex/gender in a non-oppositional and nonantagonistic way in which man is not defined in opposition to his negative, woman. This becomes particularly clear when she writes that the Yorùbá term "obìnrin" cannot mean the same as the English word "woman" because women are those without a penis and power and those who cannot participate in the public sphere (Oyěwùmí, 1997, p. 34). vi

Obinrin and okùnrin therefore exist within a gender scheme that allows for the anafemale to be simultaneously more than and different from the negative of anamale. In other words, as an identity or subject position it transcends the space of Other as found in the hierarchical gender duality. Oyĕwùmí therefore argues that obìnrin and ọùnrin express a distinction between two types of anatomy which does not connote social privilege or disadvantage (Oyĕwùmí, 1997, p. 34).

Oyĕwùmí argues that instead of gender, seniority was the organising principle in Yorùbá society that determined access to power and social hierarchy. vii In other words, there would be terms for older siblings and younger siblings, but not for male and female siblings (Oyĕwùmí,2002, p. 5). ${ }^{\text {viii }}$ Unlike sex, seniority as organising principle is context dependent and shifting, as a result "no one is permanently in a senior or junior position; it all depends on who is present in any given situation" (Oyĕwùmí, 1997, p. 42). Accordingly, identity is fluid, relational, contextual and shifting in Yorùbá society. Oyěwùmí explains that seniority, unlike gender, is only comprehensible as part of relationships and accordingly it is not "rigidly fixated 
on the body nor dichotomized" (Oyěwùmí,1997, p. 42). Oyěwùmí thus interprets gender as it features in Western society and thought as an essentialist kind of organising principle which fixes power relations and confines certain categories of people (women being the main example) to limited roles and spaces, while seniority as organising principle supports much more dynamic, relational and fluid identities and power structures.

\section{Understanding Oyěwùmí's Gender Theory in Context of the Relational Construal of Subjectivity Prevalent in African Thought}

\section{ASketch of Relationality as it Features in African Philosophy}

It is generally accepted that a major and fundamental difference between Western and African constructions of the subject and the world, is the significance of community and relationality that surface everywhere in African thought. ${ }^{\text {ix }}$

The work of Ghanaian philosopher Kwasi Wiredu, whose metaphysics has been described as the most "systematically Africa-centered to date" (Masolo, 2010, p. 11) and a philosophical reappropriation of African subjectivity (Spivak, 1999, p. 7) provides a good example of a relational notion of subjectivity. Wiredu makes of the foundational nature of personhood "the pinnacle of African difference in philosophical theory" (Masolo, 2010, p. 135). In other words, he holds the African view of personhood as relational, to constitute the most far reaching difference between African and Western systems of thought. Kenyan philosopher D.A. Masolo makes the same point by writing that "[t]he idea that the metaphysics of individual identity is almost unimaginable without a community to make it possible is a crucial and distinguishing point of contrast between African and other philosophical traditions, especially the Western variety" (Masolo, 2010, p. 134). The dominant, Western, modern self or subject in opposition to which these thinkers are asserting an African relational self, is a thinking substance whose embodied existence in a physical world among other people and beings does not pertain to its essence. This subject is thus an autonomous agent whose essence lies in its rational ability or spiritual capacity isolated from relationships with others and physical or biological situatedness. It emerges in opposition to materiality and the other. ${ }^{\times}$

Wiredu argues that the African subject challenges Western assumptions of metaphysics, epistemology and subjectivity in so far as, in Africa, the subject is understood to be ontologically and metaphysically dependent on its being in relations with others. Rather than the subject pre-existing relationships as complete and fully coherent autonomous entity, Wiredu shows throughout his work how human capacities and personhood emerge from and through relationships and socialising processes with other humans and the environment. Wiredu writes that "[t]o exist is to be somewhere, and the so-called existential "is" or "to be" corresponds to no complete thought" in the absence of an indication of place or relation (Wiredu, 1998, p. 416). To make this point Wiredu refers to Alexis Kagame, the famous Rwandan philosopher, metaphysician and linguist, who writes that:

the celebrated axiom "I think, therefore I am" is unintelligible in African thought, as the verb "to be" is always followed by and attributed to an adjunct of place: I am good, big, etc., I am in such and such a place, etc. Thus the utterance [...] "I think therefore I am" would prompt the question: "You are... what...where?" (Kagame, 1976, p. 95). ${ }^{\text {xi }}$

Accordingly, Wiredu and Kagame argue the cartesian dualistic self, which sits at the basis of the dominant modern Western view of the subject, to be wholly inapplicable to the African context. According to them, existence cannot be conceived of abstractly in the absence of concrete relations to the environment and other persons. Kenyan Christian philosopher John Mbiti famously writes in 1969 "I am, because we are; and since we are therefore I am" (1970). Contrasting this to the axiom of Descartes reveals a key difference in understanding of subjectivity in African and Western thought. According to Mbiti the essence of subjectivity in African cultures and thought is the capacity to enter into concrete relations with others, rather than having a disembodied rational mind. Existence is thought with and through material otherness rather than against or beyond it.

Other sub-Saharan African thinkers who describe subjectivity in such relational terms include Michael Oyebuchi Eze, John Murungi and Ifeanyi Menkiti. For Eze, a Nigerian anthropologist, the defining characteristic of personhood is to be in a dialogical relationship with others within a community (Eze, 2009, p. 387). Subjectivity is in part constituted by other persons with whom the subject shares the social world and that social world is constituted by shared social intercourse (Eze, 2009, p. 387). Kenyan scholar John Murungi writes that "an 
African is an African in the context of other Africans, and, as a human being, he or she is a human being in the context of other human beings" (Murungi, 2005, p. 525). Similarly, Ifeanyi Menkiti, Nigerian poet and philosopher, writes that it is the community that defines the person as a person rather than an isolated quality like rationality or will (Ifeanyi, 1984, p. 172).

Accordingly, the African communal subject is defined with reference to its embodied existence and interaction with other subjects. Subjectivity is always intersubjectivity. This means also that, unlike the modern Western subject who is supposedly autonomous, singular and insulated in so far as its true and unchanging existence sits outside the body, the subject of African communalism is embodied, exposed, socially dependent and inherently fluid because it is continuously (re)constituted in dynamic relations with other concrete others. In this sense the self is open-ended and vulnerable, rather than clearly delineated, closed off, fixed and autonomous. Murungi emphasises the fluidity of the relational subject. He writes that "one is what one is dialogically" and that "[t]o be dialogical, which necessarily is to engage others, leaves open what one is, and calls for dwelling in this openness" (Murungi, 2005, p. 525). What the subject is, is therefore never complete or final, it is determined through continuous mutual engagement with others. Subjectivity is therefore always provisional, and it is a communal and never ending endeavour in so far as it is continuously forged in dialogue with others.

Nigerian feminist scholar Amina Mama summarises the core of this relational ontology very well when she writes:

There is no word for "identity" in any of the African languages with which I can claim any degree of familiarity. Perhaps there is good reason for this. In English the word "identity" implies a singular, individual subject with clear ego boundaries. In Africa, if I were to generalise, ask a person who her or she is and a name will be followed by a qualifier, a communal term that will indicate ethnic or clan origins (Mama, 2001, p. 63).

She also writes that not only is there no all-encompassing concept for identity in big parts of Africa, but the kind of singularity that the term seemed to require is not attainable in African contexts where personhood constituted within communities (Mama, 2001, p. 64). She argues that "identity [or subjectivity] is at best a gross simplification of self-hood, a denial and negation of the complexity and multiplicity at the roots of most African communities" (Mama, 2001, p. 65). Mama thus emphasises the multiplicity, fluidity and relationality of subjectivity in African thought and cultures. She contrasts this to the singularity and stability of the Western subject.

\section{Oyĕwùmí and Relationality}

In Oyĕwùmí's description of precolonial Yorùbá society there are clear indications of a relational understanding of identity:

In the Yorùbá world, particularly in pre-nineteenth-century Oyo ${ }^{\text {xi }}$ culture, society was conceived to be inhabited by people in relation to one another. [...] Social hierarchies were determined by social relations. [...] [H]ow persons were situated in relationships shifted depending on those involved and the particular situation (1997, p. 13).

She thus posits subjectivity in precolonial Yorùbá society as inherently relational and therefore dynamic and fluid (but nevertheless material), instead of immutable, essentialised and rooted in body type, because relations between people and the contexts in which they are embedded, are continuously changing. In terms of this framework, subjectivity is rooted in exchange between concrete persons and is therefore not given or predetermined.

Moreover, in precolonial Yorùbá society subjectivity was not an "individually based, selfcontained" thing (Oyěwùmí, 2016, p. 71) and therefore subjectivity was not fixed on the basis of physical attributes. This becomes very clear in the way in which Oyěwùmí rejects the existence of the category of "woman" in precolonial Yorùbá society, because she understands it to be category which defines persons permanently and exhaustively regardless of their situatedness in specific relationships and contexts. She writes:

The upshot of this [Western] cultural logic is that men and women are perceived as essentially different creatures. Each category is defined by its own essence. [...] Consequently, whether women are in the labor room or in the boardroom, their essence is said to determine their behavior. In both arenas, then, women's behavior is by definition different from that of men (Oyěwùmí, 1997, p. 35).

Oyěwùmí regards "woman" in the colonial Western gender system to be a category based on physical attributes, that determines what you can do, where you can be, what you should 
like and not like and how you should act. Central to her insistence that "woman" did not exist in precolonial Yorùbá society, is the idea that the isolated fact of possessing certain body parts did not exhaustively define persons in precolonial Yorùbá society, nor determined and fixed the social and ontological hierarchies in which they stood toward one another. Rather, subjects were continuously reshaped in a dynamic network of relations in the system of seniority which is not "rigidly fixated on the body nor dichotomized" (Oyěwùmí, 1997, p. 42).

In this regard Menkiti's idea that the African subject is defined by the community rather than an isolated quality (Menkiti, 1984, p. 172) resonates strongly with Oyĕwùmís position. Oyĕwùmí writes that "[s]eniority, unlike gender, is relational and speaks to the collective ethos rather than to individual identity" (Oyĕwùmí, 2016,p. 10). With this I interpret her to mean that seniority is determined in interaction with others (in so far as one can be the oldest in one context while the youngest in another) while gender she reads to be a pre-established and essentialist notion that clings to individual identity (individual identity being a contradiction in terms in relational African thinking). Oyěwùmí writes further:

This seniority-based organization is dynamic, fluid, and egalitarian in that all members of the lineage have the opportunity to be senior or junior depending on the situation. The seniority-based categories are relational and do not draw attention to the body. This is very much unlike the gender or racial hierarchies, which are rigid, static, and exclusive in that they are permanently promoting one category over the other (Oyěwùmí,2016, p. 71).

Here one sees how Oyěwùmí explicitly contrasts the colonial Western gender system, in which she argues identity to be static and determined with reference only to the self in exclusion of others, on the one hand, with the indigenous Yorùbá seniority system in which identity is relational, fluid and dynamic, on the other. In this regard, Oyěwùmí's understanding of identity in a seniority-based system reminds us of Murungi's idea of the relational subject, that what one is, is established in a dialogical way and that this "leaves open what one is" and calls for "dwelling in this openness" (Murungi, 2005, p. 525). Although there is hierarchy involved, the hierarchy is always provisional, never permanent. It could be argued that it is this "dwelling in the openness" that Oyěwùmí regards to be sacrificed in the colonial Western gender system where identity is reduced to fixed and immutable categories in permanent hierarchies. In line with the prevalent view of the subject in African philosophy, the precolonial Yorùbá relational subject is fluid and is more than one thing at a time, because it is determined by a multiplicity of dynamic relationships. "Woman", as a label that places one in a category with a fixed position in society (belonging to the private domain, inferior to man), with fixed roles (nurturing, taking care of the body and the home), with fixed meaning (natural, embodied, domestic), means nothing in precolonial Yorùbá society, because there one's identity is continuously (re)determined in relation to different others.

Moreover, I read Oyĕwùmí to say that as soon as you start asking what a person is, based on the way in which the person is situated in relationships, you do not get only one answer, but many. Persons are different things in relation to different people, so that every person is many things. In other words, the relational constitution of identity in precolonial Yorùbá society renders identity plural and deferred in time. Oyěwùmí's position could therefore be explained or reinforced by Wiredu's idea that "is" or "to be" corresponds to "no complete thought" in the absence of an indication of place or relation (Wiredu, 1998, p. 416). "Woman" as a category independent of social relations and surroundings, but fixed with reference to physical attributes, did not make sense. Reading Oyěwùmí's work as being embedded in a relational understanding of subjectivity, and reading her in dialogue with the relational school in African philosophy, therefore highlights that her assertion that woman did not exist in precolonial Yorùbá society could be read to be more complex than a denial of the existence of gendered identities. Rather, it is rooted in a different construction of the subject.

A further fascinating aspect of Oyěwùmí's construction of precolonial Yorùbá society is that she seems to anchor the relational subjectivity of the precolonial Yorùbá subject in its relationship with the mother. In her latest book What Gender is Motherhood? (2016) Oyĕwùmí introduces the term "matripotency" ("supremacy of motherhood") or "matrocentricity" (centrality of motherhood) as a lens through which to understand the indigenous epistemology of the Yorùbá that has been erased or marginalised by colonialism and coloniality (Oyĕwùmí, 2016, p. 2). She writes: "[m]ore than anything else, the different construction of motherhood demonstrates the seismic shift occasioned by European colonization and policies, the establishment of notions of individualism, Christianization, 
Islamization of the culture, and globalization" (Oyěwùmí 2016: p.2). In other words, she compares the precolonial Yorùbá understanding of motherhood to the understanding of motherhood in the colonial Western gender system and she regards the differences between the two to reflect a fundamental difference in how the world and knowledge about the world are construed.

Central to Oyĕwùmí's analysis of motherhood is the significance of the bond that each person has with the mother (lya) and the role of this connection in society. The way in which Oyĕwùmí describes the lya-child relationship suggests that this connection between mother and child is central to the notion of subjectivity. She writes that "lya's relationship with their child is considered to be otherworldly, pre-earthly, preconceptional, pregestational, presocial, prenatal, postnatal, lifelong, and posthumous" (Oyěwùmí, 2016, p. 62). And the "relationship between lya and child is timeless" (Oyěwùmí, 2016, p. 62). She emphasises in many ways that the relationship with lya is the most important relationship in every person's life and that this relationship has spiritual, metaphysical, material, social and political aspects.

I read Oyĕwùmí to posit the relationship with the mother as a core element of subjectivity so that the subject cannot be thought in isolation of the mother. The relational subject of Yorùbá society is therefore first and foremost and always already and inevitably in relation with the mother. Accordingly, the subject is not singular and unified, and the subject does not have clear boundaries that separate it from what is other. Otherness is not understood as antithetical to the self, but part of the self because the self exists primarily in relation to the (m)other. ${ }^{\text {xiii }}$

Interestingly, in a similar way, Nigerian feminist philosopher Nkiru Nzegwu explicitly connects the notion of relational identity and ethics in Igbo society with this emphasis on maternal beginnings by arguing that "[m]orality begins in our awareness of our relationship to the mother" and that "[t]his relationship coordinates the formation of interpersonal experiences that helps the child define him or herself in relation to others" (Nzegwu, 2004, p. 12). Accordingly, Nzegwu argues the intersubjective and interrelational mother-child relationship to be the model for relationships among all persons. The communal ontology and ethics of the Igbo people are then rooted in the notion of motherhood. Nzegwu explains further that disloyalty to the mother or "the breakage of the uterine ties of kinship" is "tantamount to destroying the last covenant that makes our community human" (Nzegwu, 2004, p. 12). This implies that the radical acknowledgement of the bond with the mother creates a certain kind of subject that does not view itself as an autonomous individual, but as an inherently dependent and interrelational one. Humanness or subjectivity are thus defined directly with reference to maternal beginnings which remain deeply significant to personhood throughout one's life. .iv $^{\text {. }}$

Moreover, in her book What Gender is Motherhood Oyĕwùmí posits the mother as representative of universal subjectivity for the precolonial Yorùbá people. This is in contrast to the dominant notion of the universal subject of modern Western philosophy and thought, which feminism has unmasked as implicitly masculine, and defined in opposition to the feminine and material (this is a crucial theme that runs through the work of Western feminist scholars like Simone De Beauvoir, Irigaray, Christine Battersby and Adriana Cavarero among others). Oyěwùmí argues that in precolonial Yorùbá society motherhood was an ungendered category that is "representative of humanity" or the "archetypal human being" (Oyěwùmí, 2016, p. 62). Oyěwùmí writes that:

In Yorùbá culture mothers are representative of humanity, ungendered. This Yorùbá conception is in stark contrast to the male-as norm of the Western gendercentric model in which only men can represent universal human attributes (Oyěwùmí, 2011, p. 234).

According to Oyĕwùmí, the Yorùbá therefore think of subjectivity in fundamentally relational and plural terms: the universal representative of humanity is the mother who gives birth to another and whose connection with her child is timeless. Accordingly, on a metaphysical level, the subject does not exist singularly, but always in connection with the other. Oyěwùmí further argues this "matricentric" construction of the subject to be "community oriented" and contrasts it to the individuality of "Western ideologies emanating from a racist capitalist patriarchal system" (Oyěwùmí, 2016, p. 219-220). It is about understanding the self as always already and inevitably being in relation to others so that that the advancement of the well-being of the community as a whole, is central to the advancement of the well-being of the self and vice versa. 


\section{Implications of Reading Oyěwùmís Work to be Informed by the African Tradition of Relational Thought}

My reading of Oyĕwùmí could be argued to have at least three important implications. First, it contextualises, and therefore enables us to better understand, Oyěwùmís position. Second, it deconstructs the understanding of African feminism as "unAfrican". Third, it helps to bridge the disciplinary rift between African feminist thought and African philosophy. In what follows I discuss these implications.

Reading Oyĕwùmi's theorisation of the precolonial Yorùbá gender system as being rooted in the same metaphysics as one sees theorised in African philosophy, helps to render her position more convincing. Oyěwùmí understands gender in the Western colonial gender system to be a static hierarchical dichotomy in terms of which the feminine is the negative of the masculine. I read Oyěwùmi's rejection of gender to be rooted in the idea that this way of fixing identity is irreconcilable with the fluid and relational world of precolonial Yorùbá society, where subjectivity was constituted in fluid and dynamic familial and societal relations. Accordingly, I interpret Oyěwùmí to argue that gender did not exist in precolonial Yorùbá society, because human subjectivity-in-relation was not reducible to one "side" of such a rigid and dichotomous divide. Her insistence that Yorùbá identities could not be reduced to man and woman therefore makes profound sense in the context from which she is writing.

Moreover, here one sees some strong counterarguments emerging to criticisms that have been levelled against Oyěwùmí's work. Oyěwùmí's claims are controversial and have been repeatedly dismissed by certain scholars who deny the empirical veracity thereof. For example, Mama accuses Oyěwùmí of "inventing an imaginary precolonial community in which gender did not exist" (Mama, 2001, p. 69)(see also Olajubu, 2004; Matory, 2005). Even scholars who praise her for the originality and interestingness of her work, mostly do not do that without expressing reservations about the way in which she generalises in her reading of both Yorùbá culture and Western feminism (see for example King, 1998; Geiger 1999).Oyěwùmí is also criticised for the rigid and essentialist way in which she opposes Yorùbá culture to "the West", ignoring movement between them (Bakare-Yusuf, 2003). Nigerian feminist philosopher Bibi Bakare-Yusuf argues in this regard that Oyěwùmís oppositional and rejectionist attitude towards influences from elsewhere is out of step with the pluralistic approach to knowledge found in many African cultures and also among the Yorùbá (Bakare-Yusuf, 2003, p. 122). ${ }^{\text {xvii }}$

This criticism is in line with the point made in post colonial theory that the fiction of a strict divide between Africa and the West has been a preferred way through which the West constructed itself in opposition to mute "others" as part of the colonial project (see for example Hountondji, 1976; Hall, 1992; Mbembe, 2001). In this way, it can be argued that through her insistence on radical difference between Africa and the West, Oyěwùmí takes part in the process of colonial othering of African societies.

In answer to these points of criticism, it can be said that Oyĕwùmí is first and foremost making an epistemological argument. She provides us with an alternative rendition of the accepted "facts" by approaching the Yorùbá reality through a different conceptual framework or metaphysical lens, namely that of African relationality. Inherent to the alternative gender dynamics she is asserting, is a radically different construction of the subject. Her work therefore implies that if one looks at Yorùbá society through the dichotomous lens of colonial modernity, you will see a gendered society. However, if you approach the same reality through the relational lens of African philosophy, a much more fluid picture emerges, one that is not compatible or commensurate with a rigid scheme of gender binaries.

In her research on the Yorùbá, Oyěwùmí tries to show to what extent colonisation and coloniality "marginalize [...] local epistemes" (Oyěwùmí, 2016, p. 1). She writes that "in crosscultural gender studies, theorists impose Western categories on non-Western cultures and then project such categories as natural" (Oyěwùmí, 1997, p. 11). By relying on certain categories (like gender) in our research on the Yorùbá, these categories are created in the knowledge that is produced about the Yorùbá, even if they are absent in the local setting.

Her insistence on Yorùbá difference is therefore not simply a repetition of the colonial othering of Africa, but a resistant response to the idea central to modernity and coloniality that

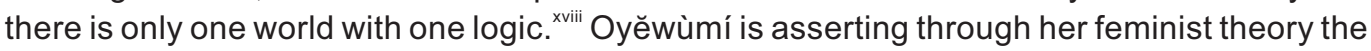
existence, validity and significance of other societies operating on their own logic, existing 
exterior/anterior to the West, ${ }^{\text {xix }}$ societies that are erased through colonialism and coloniality. She is resisting the pernicious assumption that "Western experiences define the human" (Oyĕwùmí, 1997, p. 16).

Understanding Oyĕwùmí's gender theory to be anchored in a radically different understanding of subjectivity than that which underpins Western gender configurations and theorisations, therefore not only provides context for the interpretation of her claims, but also sheds light on her insistence that precolonial Yorùbá society is irreparably distorted or erased when studied through Western conceptual paradigms. In this way it shows the key strategic relevance of the way in which she separates Africa and the West in her analysis - as an attempt to highlight and resist the epistemic erasure of African realities. By dismissing Oyĕwùmís work based on a rejection of her empirical conclusions, without engaging rigorously with the epistemological points she is making, one is therefore at risk of repeating the acts of erasure that she is trying to undo.

The second important implication of reading Oyĕwùmí as I do, is that her work can also be argued to decisively deconstruct and ultimately refute an oppositional understanding between African indigenous thought systems and gender equality or feminism.Importantly, I do not mean to deny the fact that feminisms sometimes do operate in a recolonising way in Africa by relying on exclusively Western paradigms. I mean to say that Oyěwùmí's work attests to the fact that there are ways of doing feminism that are not "unAfrican," because the gender equivalence of the precolonial Yorùbá society that she theorises, is anchored in the relational ontology and metaphysics that are described by many African scholars as characteristic of many African societies.

It could further be argued that Oyĕwùmí's feminism is not only "unAfrican", but also has significant decolonising potential. Argentinian feminist philosopher Maria Lugones (2007, 2010) argues that the categories of man and woman, where man is an active subject of reason and woman is his passive, material negative, are creations of colonial modernity that were (and still are) imposed on the realities of the colonised. She reads Oyěwùmí and postcolonial scholars such as American cultural anthropologist Irene Silverblatt (1990; 1998), American cultural historian Carolyn Dean (2001), Mexican scholar Maria Esther Pozo (Pozo\&Ledezma, 2006), Latin American anthropologist Pamela Calla, English scholar of development and environment Nina Laurie (2006), and Mexian feminist critical epistemologist Sylvia Marcos (2006), to confirm the point that gender is a colonial imposition in so far as it imposes itself on life as lived in tune with cosmologies, metaphysics or philosophies incompatible with the colonial/modern logic of dichotomies (Lugones, 2010, p. 748). Lugones's aim is then to reveal how the gender structures which are still in place today subjugate both women and men in postcolonial neocolonial societies in all domains of existence and that the transformation of gender relations is central to resist and dismantle Western hegemony and to restore, cultivate and develop subjectivities, cultures and traditions ravaged and erased by colonialism and eurocentred capitalism (Lugones, 2007, p. 189). In this sense, Oyĕwùmí's feminist work is not only aligned with African thought systems, but could also be argued to have important decolonising implications (see also Coetzee \& Du Toit, 2017).

A further interesting point in this regard is that Oyĕwùmís work highlights the possibilities that African philosophy offers for promoting gender equivalence in contemporary African societies. In other words, because Oyĕwùmís feminist position is rooted in the same fundamental assumptions as those which are so prevalent in African relational thought, her work underscores the inherent potential of this African framework to facilitate gender equivalence. Her work shows that indigenous African thought and cultures can be fundamentally congruent with certain forms of gender equivalence. In so far as the self is understood as an extended self that exists in connection with the $(\mathrm{m})$ other, a self that does not exist in exclusion of the other, but through the other, sexual difference is freed from the hierarchical and dichotomous logic that results in the exclusion, subjugation and marginalisation of femininity that is historically dominant in the colonial Western gender system and in the construction of modern Western subjectivity.

Lastly, understanding Oyĕwùmí's gender theory to be rooted in the relational understanding of subjectivity theorised by many African philosophers also highlights the profound value of incorporating feminist perspectives in African philosophy. It shows that African feminist thought could contribute in significant ways to develop African philosophy and addressing some of its weak spots. 
A major example here is the implicit masculinity of subjectivity as it is theorised in African philosophy. Musa W. Dube, a theologian from Botswana, argues that the issue of gender is visible in Africa philosophy by its absence, whereby women are either subsumed by the "we" of the Africans, or absent (Dube, 2000, p. 20). Dube's point is therefore that the seemingly gender neutral subject of African philosophy is implicitly masculine. Oyowe and Yurkivska develop this idea by arguing that African philosophers have ostensibly fallen into a genderblind essentialism (Oyowe \& Yurkivska,2014, p. 85). They explain this as follows:

What they have apparently achieved is to conceptualise what it means to be an African man while ignoring what it means to be an African woman. As a result of the assimilation of gender into other philosophical issues and the use of "man" and "he" to encompass all persons, the African discourse on personhood proceeds with a certain gender bias in favour of masculinity, which may at least partially be responsible for the subversive nature of the patriarchal tradition in Africa and the ways it continuously reinforces the status quo of male domination (Oyowe \& Yurkivska, 2014, p. 86).

They therefore argue that in the tradition of African philosophy, the gender neutrality of the subject masks a masculine bias, similar to what Oyĕwùmí (and a long line of Western feminists including Battersby and Irigaray) identifies in Western philosophy and the colonial Western gender system. The masculine represents the subject while the feminine is the other.

This absence of engagement with gender in African philosophy and the use of a (seemingly) gender neutral subject is exactly what Oyěwùmí is not promoting when she argues for the absence of "woman" in precolonial Yorùbá society. In other words, the silence on gender in African philosophy that Oyowe, Yurkivska and Dube are referring to, does not imply the same kind of ungendered subject that Oyěwùmí identifies in precolonial Yorùbá society. According to Oyĕwùmí's theory the ungenderedness of the Yorùbá subject is founded in real gender equivalence where identity is fluid and cannot be fixed in a static gender dichotomy. In contrast to this, Oyowe, Yurkivska and Dube are highlighting the way in which, implicit to African philosophy, there is a rigid gender dichotomy in terms of which the feminine is subsumed by the masculine. This dynamic is exactly what Oyĕwùmí argues not to be the case in precolonial Yorùbá society.

Oyĕwùmís work therefore implies that the fluid and relational subject of African philosophy is not dependent on, nor reconcilable with, the implicit exclusion of femininity. Her work shows that the relational subject is not singular, but plural in the sense that it also contains the other or exists in connection and in exchange with the $(\mathrm{m})$ other. In this framework, subjectivity cannot be understood as singularly and immutably masculine in exclusion of that which is other. Her work therefore suggests that the relational subject of African philosophy should be explicitly reframed and theorised to reflect the gender multiplicity, fluidity and equivalence that relationality implies. How that should be done depends on the specific African context in which each philosopher is working, but Oyĕwùmí's work suggests that failing to engage with this issue renders the African relational philosophy incoherent, contradictory and implicitly reliant on the dichotomies of Western colonial thinking.

\section{Conclusion}

In this article I argued that Oyěwùmí's feminist position shares certain core assumptions with the relational understanding of subjectivity that is so dominant in African philosophy. It was seen that many African philosophers assert, in different ways and with regard to many different African cultures, the existence of a fluid, relational and non-dichotomous subjectivity where identity is not constituted in opposition to that which is other, but in relation to otherness.

Understanding the precolonial realities posited and theorised by Oyěwùmí in terms of the relational metaphysics so prominent in African thought, sheds new light on her position. If Oyĕwùmí is understood to subscribe to a relational and non-dichotomous understanding of subjectivity in terms of which subjects are constituted in relation with others who are different, her rejection of the existence of the categories of man and woman in precolonial Yorùbá society can be read as a rejection of the existence of a subject defined by sameness, stability and dichotomy, in favour of one who was defined by difference, fluidity and multiplicity. Accordingly, I do not understand her to be saying that the precolonial Yorùbá society was blind to sexual differences. Rather, woman as an inherently inferior being, with a determined and static gender and sexual position and defined in opposition to and as negative to man, did not 
exist. She therefore presents an order in which gender cannot exist in the same way as it does in the Western symbolic order. In other words, by bracketing dominant Western conceptual frameworks and trying to root her theoretical position in concrete aspects of precolonial Yorùbá reality, she shows how Yorùbá society was founded in a different logic than that which underpins dominant Western understandings of gender. By rooting her claims in "endogenous categories and epistemologies" (Oyĕwùmí, 2016, p.1), Oyĕwùmí resists the epistemic erasure of the Yorùbá reality.

Importantly, Oyěwùmí's work also confronts African philosophy with some of its limitations. In this regard I argued that Oyĕwùmí's work poses a challenge to the seemingly neutral but implicitly masculine subject of African philosophy and highlights the need to explicitly engage with the gender implications of relational subjectivity. Moreover, Oyěwùmí's work suggests that the African tradition of relational thought can be interpreted to inherently support a certain form of gender equivalence and offer resistance to patriarchal oppression, in so far as it is centred on a fluid, plural and relational conception of subjectivity. Reading Oyěwùmí together with African philosophy therefore shows the inherent feminist potential of African relationality, something that is almost completely neglected in the academic tradition of African philosophy so far. Oyĕwùmí's work thus attests to the unique potential of incorporating African feminist voices in African philosophy as a force that could work to strengthen, deepen and develop the existing knowledge frameworks. In this way Oyěwùmí's work could be interpreted to deconstruct and bridge the fundamental tension between (African) feminism on the one hand and indigenous African cultures and thought on the other, by presenting us with a feminist position that is specifically anchored in African thought systems.

The distinction between sex and gender arose in the 1970s, and in terms of this distinction sex is regarded as referring to the biological traits that distinguish men from women, and gender is understood as the social, cultural and sexual attitude or identity that accompanies the biologically sexed body. However, feminist scholars like Judith Butler (1990) and Elizabeth Grosz (1994) have forwarded convincing arguments, which are widely accepted in feminist scholarship, about the incoherence of the sex/gender distinction. On this basis I use these terms interchangeably in this article.

ii Scholars like Sanya Osha ascribe this to the fact that Africa inherited the inherently masculinist aspects of Western philosophy (2006).

iii See also the work of Nigerian writer, novelist, poet and academic Femi Ojo-Ade (1983) who vehemently criticises feminism as being "unAfrican" and Nigerian poet, writer and journalist lbekwe Chinweizu (1990) who dismisses feminism on the same basis.

iv Du Toit explains in this regard that women's sexual rights (or absence thereof) are often used as a favoured marker of collective ethnic, religious and cultural identity and is treated as a core aspect of that identity (2013,17-18). Construing feminist demands as purely external and in opposition to culture is used as a gesture of opposing Western or other external influences and stabilising the national identity through the control of women's sexed bodies (Du Toit, 2013, p. 30). An obvious example of this is how the practice of female circumcision is vehemently defended and upheld in many parts of Africa in the name of protecting culture.

${ }^{\vee}$ Despite this, a strong body of African feminist scholarship has developed across various disciplines. Examples of prominent feminist figures today in African scholarship and popular culture (apart from Oyěwùmí) are Amina Mama, a Nigerian psychologist who has addressed women in government and politics in a variety of African contexts, such as militarism, women's organisations and movements, race and subjectivity; Sylvia Tamale, a Ugandan feminist legal scholar who works on Third World women and the law and gender and sexuality among other things; NkiruNzegwu a Nigerian Igbo artist, philosopher and feminist scholar who publishes on African art, culture and philosophy, and feminist literary scholars Grace Musila and Chielozona Eze. However, importantly, feminist voices remain marginal to most African intellectual contexts and completely absent from others, most notably philosophy.

vi Mexican decolonial scholar Rolando Vazqúez (2011) works with Oyĕwùmí's claims to make his argument about how translation functions to act as a mechanism of modernism to effect epistemic exclusion, erasure and oppression. See also Mignolo, 2005.

vii Seniority refers to chronological age difference and also to the positioning of persons within the lineage structure on the basis of whether they were born into the lineage structure or joined through marriage, and if the latter is the case, at what point they joined.

viii For an in depth critique of this etymological approach of Oyěwùmí, see Bakare-Yusuf (2003) and Peel (2002, p. 138-139). 
${ }^{i x}$ My account of relational African thought is necessarily a partial and selective construction. African philosophy, although rather young, constitutes a vast and diverse body of work, and deals with thought emerging from countless different cultural groupings and histories. For every point I make it is thus probably possible to find an African philosopher who asserts the opposite. However, that said, I do think African philosophies of communality or relationality are characterised by certain overarching trends and themes that mark some central differences between this body of thought and traditional Western philosophy. It is on these overarching trends that I will be focusing in order to make a broad point about the kind of metaphysical assumptions that also underpin the work of Oyěwùmí.

' Two of the most famous examples of this would be Descartes' thinking subject and Kant's transcendental subject of thought with an autonomous rational will. However, to describe the Western philosophical subject like this, also constitutes a generalisation. It can be said that both Descartes and Kant theorised the subject in more nuanced terms than what they are often credited for in the philosophical tradition. Moreover, this view of the subject as disembodied thinking substance has recently been subjected to extensive criticism within the Western philosophical tradition, starting with Husserl, Nietsche and Heidegger and culminating in the work of Derrida, Lyotard and Foucault. Also, feminist philosophy has shown in various ways and on various levels how this is an incomplete account of subjectivity that serves the oppression of women (this can be seen throughout the work of Butler, Irigaray, Grosz, Kristeva and many more). Accordingly, although the notion of the disembodied self extends into contemporary Western thought, it is problematised within the tradition. When I contrast it to the dominant African relational notion of the subject (which is also contested terrain), I therefore use it as the dominant view of Western colonial modernity which has shaped Western philosophy into what it is today and which the African scholars reject, without claiming that it is the only view.

${ }^{x i}$ Wiredu explains that although Kagame refers to the Bantu speaking peoples, his remark applies to the construal of existence in other language areas in Africa too (Wiredu, 1998, p. 416).

${ }^{x i}$ This refers to a specific Yorùbá kingdom.

xiii This can be compared to the way in which British feminist philosopher Christine Battersby explores an understanding of subjectivity that makes woman rather than man typical of subjectivity and which thinks in terms of relations of dependence in her book Phenomenal Woman: Feminist Metaphysics and the Patterns of Identity (1998). Battersby seeks to formulate a model of identity that is not dependent on the exclusion of that which is other, but one that exists through engagement and in relation with others. The comparison between Battersby and Oyěwùmí shows how deep the difference is that Oyěwùmí is asserting between the Yorùbá gender system and the global capitalist Western colonial/modern gender system. The precolonial Yorùbá subject and world closely resembles that which Battersby thinks up as a radical alternative to Western metaphysics. This emphasises the way in which Oyěwùmí is not merely representing an alternative theory on gender equivalence. Her position is rooted in an entirely different way of constructing the subject and the world: where self and other, transcendence and immanence, body and mind etc., are thought in fluid continuity rather than oppositions, where the self is an extended self and where the world is a non-dichotomous whole.

xiv This relationship between motherhood and relational ontology could be an interesting line of thinking to explore further in the vast body of African scholarship and literature that engages with motherhood and its importance in society. See for example the work of Yvonne Vera, Catherine Achonolu, Mercy Oduyoye and Buchi Emecheta, among many others.

${ }^{x v}$ There are many Western feminist philosophers who make the same point, including Simone de Beauvoir (1949) and Luce Irigaray (1985).

xvi Oyěwùmí is criticised also on other theoretical grounds by Olupona (2002), Bakare-Yusuf (2003) Peel (2002) and Olajubu $(2004,2003)$ among others.

xvii There are of course also scholars who agree with Oyĕwùmí. For example, sociologist Jimi O. Adesina argues that unlike a lot of African scholars, Oyěwùmí does not merely supply data to validate Western theory, but allows her data to produce conceptual outcomes appropriate to the uniqueness of the data, often challenging Western theory, concepts and assumptions. Because she took her locale seriously enough to engage with it without undue anxieties of what established Western knowledges have to say, she enabled "an important, epistemic, shift in our understanding of a global idea of gender" (Adesina, 2010 , p. 9). There are also postcolonial scholars like Maria Lugones (2007 and 2010) and Greg Thomas (2007) who, although not specifically bestowing praise, seem to accept the validity and significance of Oyěwùmís position, and who incorporate her arguments into their scholarship. The same goes for the Nzegwu who does not often refer to Oyĕwùmí directly, but whose research on the Igbo resonates, on a general, philosophical level, with a lot of what Oyěwùmí is saying with regard to the Yorùbá.

xviii Lugones draws a distinction between the modern and the pre-modern that articulates this point very well. She explains that modernity exercises control through the denial of the existence of other worlds with different ontological presuppositions (Lugones, 2010, p. 749). Modernity constructs the exteriority of modernity as pre-modern (Lugones, 2010, p. 749). Postcolonial historian Dipesh Chakrabarty similarly refers to the "ffirst in Europe and then elsewhere" structure of time', which refers to the idea that "[w]e were all headed for the same destination [...] but some people were to arrive earlier 
than others" (Chakrabarty, 2000, p. 8). In this sense "Europe' remains the sovereign, theoretical subject of all histories" and all histories tend to become variations on the master narrative that could be called "the history of Europe" (Chakrabarty, 2000, p. 27).

${ }^{x i x}$ With exteriority I do not mean a pure outside, untouched by colonial modernity. I use in the sense described by Latin American postcolonial scholar Arturo Escobar who does not refer to exteriority as an ontological outside, but as "an outside that is precisely constituted as difference by a hegemonic discourse" (Escobar, 2007, p. 186). He writes that "[t]his interpellation of the Other comes from outside or beyond the system's institutional and normative frame, as an ethical challenge" (Escobar, 2007, p. 186).

${ }^{x x}$ See for example the work of Nzegwu, who shows how Western feminism often makes itself guilty of grossly distorting and erasing African realities by reading African societies through Western conceptual frameworks, a process that Nzegwu labels as the reduction of African peoples and cultures to "vapid forms into Western imagination" (Nzegwu, 1996, p. 176). This problematic was also delineated strikingly in the seminal work Third World Women and the Politics of Feminism (1986) edited by postcolonial scholars Chandra Talpade Mohanty, Ann Russo and Lourdes Torres. In her essay, Mohanty argues famously that Western feminist theory presents itself as a universal phenomenon in ways that disguise its profoundly Western concerns and biases. 


\section{References}

Adésínà, O. (2010). Re-appropriating Matrifocality: Endogeneity and African Gender Scholarship. African Sociological Review, 14(1): 2-19.

Bakare-Yusuf, B. (2003). "Yorùbás don't do gender": a critical review of Oyèrónké Oyěwùmí”s The Invention of Women: Making an African Sense of Western Gender Discourses. African Identities, 1(1), 121-142.

Battersby, C. (1998). The Phenomenal Woman: Feminist Metaphysics and the Patterns of Identity. New York: Routledge.

Butler, J. (1990). Gender Trouble: Feminism and the Subversion of Identity. New York: Routledge.

Chakrabarty, D. (2000). Provincializing Europe: Postcolonial Thought and Historical Difference. Princeton: Princeton University Press.

Chinweizu, I. (1990). Anatomy of Female Power: A Masculinist Dissection of Matriarchy. Lagos: Pero Press.

Chukukere, G. (1998). An Appraisal of Feminism in the Socio-political Development of Nigeria. In O. Nnaemeka (Ed.), Sisterhood, Feminism and Power: From Africa to the Diaspora (pp. 133-148) . Trenton: African World Press.

Coetzee, A. \& Du Toit, L. (2017). Facing the sexual demon of colonial power: Decolonising sexual violence in South Africa. European Journal of Women's Studies.

De Beauvoir, S. (1949). The Second Sex (trans. H.M. Parshley)London: Vintage Books.

Dean, C. (2001). Andrean androgyny and the making of men. InC. Klein (Ed.), Gender in pre-Hispanic America (pp.143-177). Washington D.C.: Dumbarton Oaks.

Du Toit, H.L. (2008). "Old wives" tales and philosophical delusions: on "the problem of women and African philosophy." South African Journal of Philosophy, 27(4), 413-428.

Du Toit, H.L. (2013). In the Name of What? Defusing the Rights-Culture Debate by Revisiting the Universals of Both Rights and Culture. Politikon: South African Journal of Political Studies, 40(1), 15-34.

Escobar, A.(2007). Worlds and Knowledges Otherwise. Cultural Studies, 21(2-3), 179-210.

Eze, C. (2015). Feminist Empathy: Unsetting African Cultural Norms in The Secret Lives of Baba Segi's Wives. African Studies, 74(3), 310-326.

Eze, M.O. (2009). What is African Communitarianism? Against Consensus as a regulative ideal. South African Journal of Philosophy, 27(4), 386-399.

Geiger, S. (1999). Women and Gender in African Studies - The Invention of Women. African Studies Review, 42(3), 21-33.

Grosz, E. (1994). Volatile Bodies: Toward a Corporeal Feminism. Bloomington: Indiana University Press.

Hall, S. (1992). The West and the Rest: Discourse and Power. In S. Hall \& B. Gieben (Eds.), Formations of Modernity (pp. 275-332). Cambridge: Polity Press.

Hountondji, P. (1976). African philosophy: Myth and reality. London: Hutchinson.

Irigaray, L. (1985). Speculum of the Other Woman (trans. C.G. Gill). Ithaca: Cornell University Press.

Kagame, A. (1976). Comparative Bantu Philosophy. Paris: Présence Africaine.

King, A. (1998). Review of Invention of Women. World Literature Today, 72(4), 880.

Lugones, M. (2007). Heterosexualism and the Colonial/Modern Gender System. Hypatia, 22(1),186-209.

Lugones, M. (2010). Toward a Decolonial Feminism. Hypatia, 25(4), 242-259.

Mama, A. (2001). Challenging Subjects: Gender and Power in African Contexts (Plenary Address, Nordic Africa Institute Conference, 'Beyond Identity: Rethinking Power in Africa', Upsala, October 47th). African Sociological Review, 5(2), 63-73.

Marcos, S. (2006). Taken from the lips: Gender and eros in mesoamerican religions. Leiden: Brill. 
Masolo, D.A. (2010). Self and Community in a Changing World. Bloomington: Indiana University Press.

Matory, J.L. (2005). Sex and the empire that is no more: Gender and the politics of metaphor in Oyo Yorùbá Religion. New York: Berghahn Books.

Mbembe, A. (2001). On the Postcolony. London: University of California Press.

Mbiti, J.S. (1970). African Religion and Philosophy. New York: Doubleday Anchor.

Menkiti, I.A. (1984). Person and Community in African Traditional Thought. In R. Wright(Ed.), African Philosophy, an Introduction (pp. 171-182). Lanham: University Press of America.

Metz, T. (2011). African Conceptions of Human Dignity: Vitality and Community as the Ground of Human Rights. Human Rights Review, 13,19-37.

Mignolo, W. (2005). The Idea of Latin America. Oxford: Blackwell Publishing.

Mohanty, C. (1984). Under Western Eyes: Feminist Scholarship and Colonial Discourses. Boundary 2, $12 / 13,333-358$

Murungi. J. (2005). The Questions of African Jurisprudence: Some Hermeneutic Reflections. In K. Wiredu (Ed.), A Companion to African Philosophy (pp. 519-526.) Oxford: Blackwell Publishing.

Nzegwu, N. (1996). Questions of Identity and Inheritance: A critical review of Kwame Anthony Appiah's In My Father's House. Hypatia, 11(1), 175-201.

Nzegwu, N. (2004). Seeing Through a Woman's Eye: Yorùbá Religious Tradition and Gender Relations. Journal of Feminist Studies in Religion, 20(1), 41-60.

Ojo-Ade, F. (1983). Female Writers, Male Critics. African Literature Today, 13, 158-179.

Olajubu, O. (2003). Women in the Yorùbá Religious Sphere. New York: State University of New York Press.

Olajubu, O. (2004). Seeing Through a Woman's eye: Yorùbá Religious Tradition and Gender Relations. Journal of Feminist Studies in Religion, 20(1), 41-60.

Olupona, J.K. (2002). Imagining the power of the Goddess: gender in Yorùbá Religious Traditions and Modernity, Lecture, Princeton: Princeton University.

Oluwole, S. (1998). Africa. In A. Jagger \& I.M. Young (Eds.), A Companion to Feminist Philosophy (pp. 96-107). Malden: Blackwell.

Osha, S. (2006). Philosophy and figures of the African female. Quest: An African Journal of Philosophy, 20(1-2), 155-204.

Oyĕwùmí, O. (1997). The Invention of Women: Making an African Sense of Western Gender Discourses. Minnesota: University of Minnesota Press.

Oyěwùmí, O. (2002). Conceptualizing Gender: the Eurocentric Foundations of Feminist concepts and the Challenge of African Epistemologies. JENdA: A Journal of Culture and Women Studies, 2(1), 1-9.

Oyěwùmí, O. (2011).Gender Epistemologies in Africa: Gendering Traditions, Spaces, Social Institutions, and Identities. New York: Palgrave MacMillan.

Oyĕwùmí, O. (2016). What gender is motherhood: Changing Yorùbá Ideals of Power, Procreation and Identity in the Age of Modernity. New York: Palgrave.

Oyowe, O. A., \& Yurkivska, O. (2014). Can a Communitarian Concept of African Personhood be both Relational and Gender-neutral? South African Journal of Philosophy, 33(1), 85-99.

Peel. J. D. Y. (2002). Gender in Yorùbá Religious Change. Journal of Religion in Africa, 32, 136-166.

Pozo, M.E., \& Ledezma, J. (2006). Genero: trabajo agricola y tierra en Raqaypampa. In E. Laurieand M.E. Pozo (Eds.), Las displicencias de genero en los cruces del siglo pasado al Nuevo milenio en los Andes. Cochabamba: CESU-UMSS.

Silverblatt, I. (1990). Taller de historia oral Andina.La Mujer Andina en la historia. Chuckiyawu: Ediciones del THOA.

Silverblatt, I. (1998). Moon, sun, and witches. Princeton: Princeton University Press.

Spivak, G.C. (1999). A Critique of Post colonial Reason: Toward a History of the Vanishing Present. Cambridge: Harvard University Press. 
Thomas, G. (2007). The Sexual Demon of Colonial Power: Pan-African Embodiment and Erotic Schemes of Empire. Bloomington: Indiana University Press.

Vázquez, R. (2011). Translation as Erasure: Thoughts on Modernity's Epistemic Violence. Journal of Historical Sociology, 24(1), 27-44.

Wiredu, K. (1998). Toward Decolonizing African Philosophy and Religion. African Studies Quarterly, 1(4), 18-46. 